\title{
Utilization of Alumina Waste and Silica Waste for Geopolymer Production
}

\author{
Petchporn Chawakitchareon*, and Plengprapkun Kingthong \\ Department of Environmental Engineering, Faculty of Engineering, Chulalongkorn University, Bangkok \\ 10330, Thailand \\ E-mail: *petchporn.c@chula.ac.th (Corresponding author)
}

\begin{abstract}
This research studies the utilization of alumina waste and silica waste for geopolymer production. Alumina waste was obtained from aluminium thermal metallurgy industry, silica waste was obtained from silicone recycle industry in Thailand. This present study aimed at investigating the basic physical and chemical properties of waste materials and also the optimal proportion in geopolymer production. The results revealed that alumina waste contained 48 percent of aluminium oxide, 4.18 percent of Silicon dioxide and average particle size is 36 micrometers. Silica waste contained 71.3 percent of Silicon dioxide and average particle size is 49 micrometers. The leaching tests of heavy metals also indicated that the level of all heavy metals concentration were over the standard set by the Ministry of Industry, Thailand which means both alumina and silica waste were considering as hazardous waste. In geopolymer production, the mortar was cast in $5 \times 5 \times 5$ centimeters cubic shape for both methods with cured temperature at 60 degree celsius. Compressive strength was tested at 1, 7,14 and 28 days. The results revealed that the best $\mathrm{SiO} 2 \mathrm{Al} 2 \mathrm{O} 3$ ratio must be 3:1 mixed by alumina waste $46 \mathrm{~g}$. and silica waste $24 \mathrm{~g}$. with 10 $\mathrm{ml}$ of sodium hydroxide and $20 \mathrm{ml}$ of sodium silicate. This proportion gain the highest compressive strength for $262.8 \mathrm{~kg} / \mathrm{cm} 2$ at 28 days of curing which over the standard for hollow load-bearing concrete masonry units (TIS57-2530) and costs $4.03 \mathrm{THB} /$ mortar. The leaching tests were estimated again after the production of geopolymer. The results indicated that the concentration of all heavy metals was within the standard set by the Ministry of Industry, Thailand. Therefore the production of geopolymer mortar from alumina waste and silica waste were not considering as hazardous waste.
\end{abstract}

Keywords: Alumina waste, silica waste, geopolymer, waste utilization.

ENGINEERING JOURNAL Volume 20 Issue 4

Received 3 March 2016

Accepted 13 June 2016

Published 1 August 2016

Online at http://www.engj.org/

DOI:10.4186/ej.2016.20.4.51 


\section{Introduction}

Portland cement-based products are the world's most commonly used building materials. In the making of Ordinary Portland Cement (OPC), for manufacturing of 1 ton of cement calls for 1.7 tons of prime materials and involves the emission of 0.8 tons of carbon dioxide into the atmosphere [5]. Cement manufacturing industry is estimated to account for around 6-7\% of entire global carbon dioxide emissions and also consume enormous amount of rock extraction for quarried and minerals that may lead to deplete at one point of time [9]. To keep the global environmental safe from the consequence of cement production, it is important to explore the alternative materials that can completely or partially eliminate the use of cement in concrete and cause no environmental destruction. In recent time, to lower the environmental impact due to cement manufacturing, a new binding material is made from an aluminosilicate precursor activated in high alkaline solution [8]. This binding agent is known as geopolymer cement. Alumina waste obtained from aluminium thermal metallurgy plant and silica waste from silicone recycle industry were used as the raw material of the geopolymer production. These 2 types of waste were generally disposed by stabilization method and dumped into the security landfill. The aim of this research is to take an advantage of their properties, due to silica and alumina are the main element consisted in their composition which are the most important element to generate the aluminosilicate gel in geopolymerization process and to study the method of the utilization of alumina and silica waste in order to avoid the waste disposal cost. In forming of the alumino-silicate bonds, sodium hydroxide and sodium silicate the alkaline activated solution required to activate the source materials alumina waste and silica waste. In addition, the geopolymer production can reduce the contaminant leachability by both physical (adsorption or encapsulation) and chemical (fixation) means to convert the hazardous waste into an environmentally acceptable waste form for land disposal or construction use [3].

\section{Materials and Methods}

\subsection{Materials and preparation}

The raw materials were alumina waste and silica waste, illustrated in Fig 1. Alumina waste was obtained from aluminium thermal metallurgy plant and silica waste from silicone recycle industry in Thailand. Both materials were milled within the tube mill for 2 hours to reduce the particle size estimated by Mastersizer 3000. The chemical composition of alumina waste and silica waste were determined by X-ray fluorescence. Total concentration of heavy metal in leachate were tested to compare with Total Threshold Limit Concentration (TTLC) and Soluble Threshold Limit Concentration (STLC) specified by The Ministry of Industry of The Kingdom of Thailand and the microstructure of the waste particle was captured by Scanning Electron Microscope (SEM) and show in Fig 2. All of the physicochemical properties are depicted in Table 1.

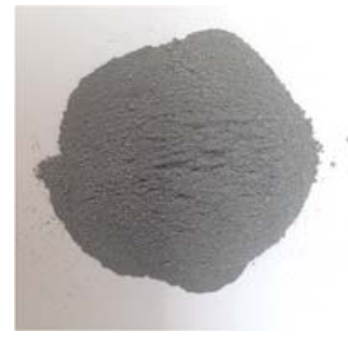

(a)

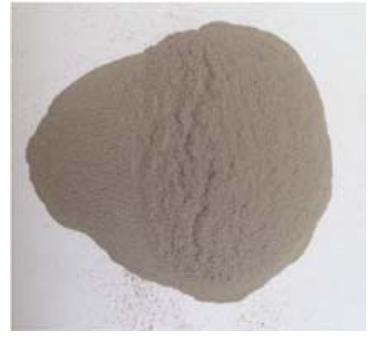

(b)

Fig 1. Raw materials (a) Alumina waste, (b) Silica waste. 
Table 1. Physicochemical properties of alumina waste and silica waste.

\begin{tabular}{|c|c|c|c|}
\hline \multicolumn{2}{|c|}{ Physicochemical properties } & Alumina Waste & Silica Waste \\
\hline \multirow{5}{*}{ Chemical composition ( $\%$ by weight) } & $\mathrm{Al}_{2} \mathrm{O}_{3}$ & 48.094 & $<0.01$ \\
\hline & $\mathrm{SiO}_{2}$ & 4.18 & 71.3 \\
\hline & $\mathrm{CaO}$ & 1.51 & 0.02 \\
\hline & $\mathrm{Fe}_{2} \mathrm{O}_{3}$ & 3.066 & 0.08 \\
\hline & \%LOI* & - & 28.6 \\
\hline Particle size (Micrometer) & & 36 & 48.9 \\
\hline \multirow{4}{*}{ Heavy metal concentration $(\mathrm{mg} / \mathrm{kg})$} & $\mathrm{Cr}$ & 82.5 & 324 \\
\hline & $\mathrm{Cu}$ & 2.98 & 189 \\
\hline & $\mathrm{Pb}$ & 7.95 & 1852 \\
\hline & $\mathrm{Zn}$ & 0 & 5368 \\
\hline \multirow{4}{*}{ Heavy metal concentration $(\mathrm{mg} / \mathrm{l})$} & $\mathrm{Cr}$ & 6.15 & 1.07 \\
\hline & $\mathrm{Cu}$ & 0 & 1.61 \\
\hline & $\mathrm{Pb}$ & 0.76 & 26.3 \\
\hline & $\mathrm{Zn}$ & 0 & 11.9 \\
\hline
\end{tabular}

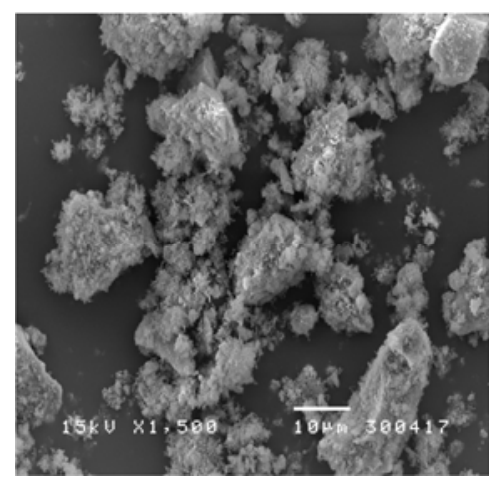

(a)

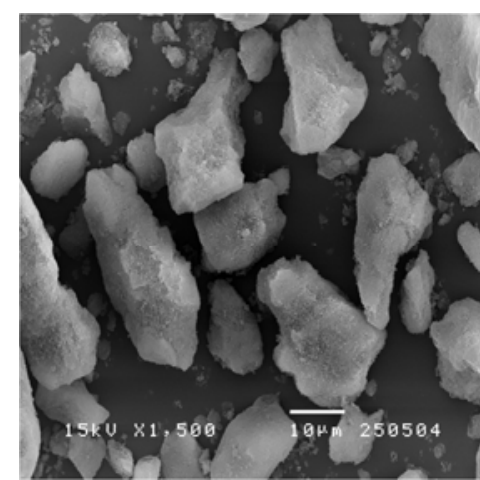

(b)

Fig 2. Microstructure images of (a) Alumina waste, and (b) Silica waste.

\subsection{Methods}

\subsubsection{Preparation of Geopolymer Mortar Samples}

Every geopolymer samples were casted in $5 \times 5 \times 5$ centimeter cubic shape and cured at 60 degree celsius for 24 hours. The samples were composed of alumina waste, silica waste, sodium hydroxide, sodium silicate and sand. The proportion of alumina waste and silica waste controlled by $\mathrm{SiO} 2 / \mathrm{Al} 2 \mathrm{O} 3$ within the total amount of raw waste material (70 grams) and ratio of $\mathrm{SiO} 2 / \mathrm{Al} 2 \mathrm{O} 3$ are 1,2 and 3. The alkaline activated solutions are sodium hydroxide and sodium silicate combined in $30 \mathrm{ml}$, the ratios of $\mathrm{NaOH} / \mathrm{Na} 2 \mathrm{SiO} 3$ are 2 , 1 and 0.5 . The amount of sand in every sample was fixed at $275 \mathrm{gram}$. All the proportion details are shown in Table 2. 
Table 2. Proportion detail of all the geopolymer samples.

\begin{tabular}{cccccccc}
\hline Sample & $\mathbf{S i} / \mathbf{A l}$ & $\begin{array}{c}\text { Silica } \\
\text { waste } \\
(\mathbf{g})\end{array}$ & $\begin{array}{c}\text { Alumina } \\
\text { waste } \\
(\mathbf{g})\end{array}$ & $\mathbf{N a O H} / \mathbf{N a}_{2} \mathbf{S i O}_{3}$ & $\begin{array}{c}\mathbf{N a O H} \\
(\mathbf{m l})\end{array}$ & $\begin{array}{c}\mathbf{N a}_{2} \mathbf{S i O}_{3} \\
(\mathbf{m l})\end{array}$ & $\begin{array}{c}\text { Sand } \\
(\mathbf{g})\end{array}$ \\
\hline A1B1 & 1 & 27 & 43 & 2 & 20 & 10 & 275 \\
$\mathrm{~A} 1 \mathrm{~B} 2$ & 1 & 27 & 43 & 1 & 15 & 15 & 275 \\
$\mathrm{~A} 1 \mathrm{~B} 3$ & 1 & 27 & 43 & 0.5 & 10 & 20 & 275 \\
$\mathrm{~A} 2 \mathrm{~B} 1$ & 2 & 40 & 30 & 2 & 20 & 10 & 275 \\
$\mathrm{~A}$ 2B2 & 2 & 40 & 30 & 1 & 15 & 15 & 275 \\
$\mathrm{~A} 2 \mathrm{~B} 3$ & 2 & 40 & 30 & 0.5 & 10 & 20 & 275 \\
$\mathrm{~A} 3 \mathrm{~B} 1$ & 3 & 46 & 24 & 2 & 20 & 10 & 275 \\
$\mathrm{~A} 3 \mathrm{~B} 2$ & 3 & 46 & 24 & 1 & 15 & 15 & 275 \\
A3B3 & 3 & 46 & 24 & 0.5 & 10 & 20 & 275 \\
\hline
\end{tabular}

\subsubsection{Compressive Strength Measurement}

The geopolymer specimens were tested for compressive strength for different curing time $(1,7,14$ and 28 days) by using a 150 ton concrete compression machine according to ASTM C109/C109M [4].

\subsubsection{Leaching of Heavy Metal}

Preparing sample by acid digestion following US.EPA method 3050b [6] to compare its concentration (mg/kg) with Total Threshold Limit Concentration (TTLC) standard and assess the heavy metal concentration again by following Waste Extraction Test method to compare with Soluble Threshold Limit Concentration (STLC) standard set by the Ministry of Industry.

\subsubsection{Microstructure of Sample}

Select the highest compressive strength sample to estimate its microstructure and compare with the microstructure of the lowest compressive strength sample by using Scanning Electron Microscopy (SEM).

\section{Results and Discussion}

\subsection{Compressive Strength}

The results of compressive strength were given in Table 3 and Fig 3. The compressive strength of geopolymer samples were in the range from 51.6 to $155.2 \mathrm{~kg} / \mathrm{cm} 2$ for 1 day curing and developed when curing time increase. For instance, The compressive strength of sample estimated at 28 days of curing were in the range from 92.6 to $262.8 \mathrm{~kg} / \mathrm{cm} 2$. Show that the compressive strength and the curing time are the direct variation that means the compressive strength is developed while the curing time is increased.

To find the best composition of geopolymer mortars, the ratio of binder and alkaline activated solution were determined. Focus on the $\mathrm{Si} / \mathrm{Al}$ ratio, the result showed that all samples gain more compressive strength when the $\mathrm{Si} / \mathrm{Al}$ ratio increased [2]. From the chemical standpoint, the most important factor in geopolymer formation is the silica and reactive alumina content in starting aluminosilicate, because silicon is the main component of the structural skeleton of the reaction products formed during the alkaline activation of the materials $[1,10]$. At the ratio of $\mathrm{Si} / \mathrm{Al}=1$ testing at 28 days of curing, The compressive strength were in the range from 92.6 to $117.6 \mathrm{~kg} / \mathrm{cm}^{2} . \mathrm{Si} / \mathrm{Al}=2$, the strength were increased in the range from 171 to $232 \mathrm{~kg} / \mathrm{cm}^{2}$ and for the ratio of Si $/ \mathrm{Al}=3$, the samples gained the most compressive strength in the range between 193.4 to $262.8 \mathrm{~kg} / \mathrm{cm}^{2}$. In addition to the condition of forming of the geopolymer sample, the ratios of alkaline activated solution were estimated because alkaline activated solution is the main factor to activate the geopolymerization process [11]. The results show that at the ratio of $\mathrm{NaOH} / \mathrm{Na}_{2} \mathrm{SiO}_{3}=2$, the sample gained the lowest compressive strength at every curing period and it will be increased when the ratio of $\mathrm{NaOH} / \mathrm{Na}_{2} \mathrm{SiO}_{3}$ decline. The best ratio that gives the highest compressive strength is 0.5 . After the estimate of compressive strength data, A3B3 sample is the best proportion for this 
research which gave the highest compressive strength for every curing time $(1,7,14$ and 28 days). It composed of alumina waste and silica waste in the $\mathrm{Si} / \mathrm{Al}$ ratio $=3$ and the alkaline activated solution ratio $\left(\mathrm{NaOH} / \mathrm{Na}_{2} \mathrm{SiO}_{3}\right)=0.5$. This proportion gained the highest compressive strength for $262.8 \mathrm{~kg} / \mathrm{cm} 2$ at 28 days of curing which over the standard for hollow load-bearing concrete masonry units (TIS57-2530) [12] and standard for hollow non-load-bearing concrete masonry units (TIS58-2530) [13].

In conclusion, it is clear that both of the ratios of $\mathrm{Si} / \mathrm{Al}$ and $\mathrm{NaOH} / \mathrm{Na}_{2} \mathrm{SiO}_{3}$ have an effect on geopolymer formation. The highest compressive strength is made by the sample composed of $\mathrm{Si} / \mathrm{Al}=3$ and $\mathrm{NaOH} / \mathrm{Na}_{2} \mathrm{SiO}_{3}=0.5$ and can develop by increasing of the curing time.

Table 3. The results of compressive strength of the geopolymer sample.

\begin{tabular}{ccccc}
\hline & \multicolumn{4}{c}{ Compressive strength $\left.\mathbf{( K g} / \mathbf{c m}^{2}\right)$} \\
Sample & 1 day & 7 days & 14 days & 28 days \\
\hline A1B1 & 51.6 & 73 & 84.2 & 92.6 \\
A1B2 & 63.4 & 85.6 & 93.6 & 101.8 \\
A1B3 & 72 & 93.4 & 106.2 & 117.6 \\
A2B1 & 101.4 & 125.6 & 146.2 & 171 \\
A2B2 & 118.4 & 134.4 & 142.4 & 191.4 \\
A2B3 & 134.8 & 164 & 190.8 & 232 \\
A3B1 & 123.4 & 144.8 & 163.6 & 193.4 \\
A3B2 & 140.6 & 169.2 & 190.2 & 230.4 \\
A3B3 & 155.2 & 189.6 & 215 & 262.8 \\
\hline
\end{tabular}

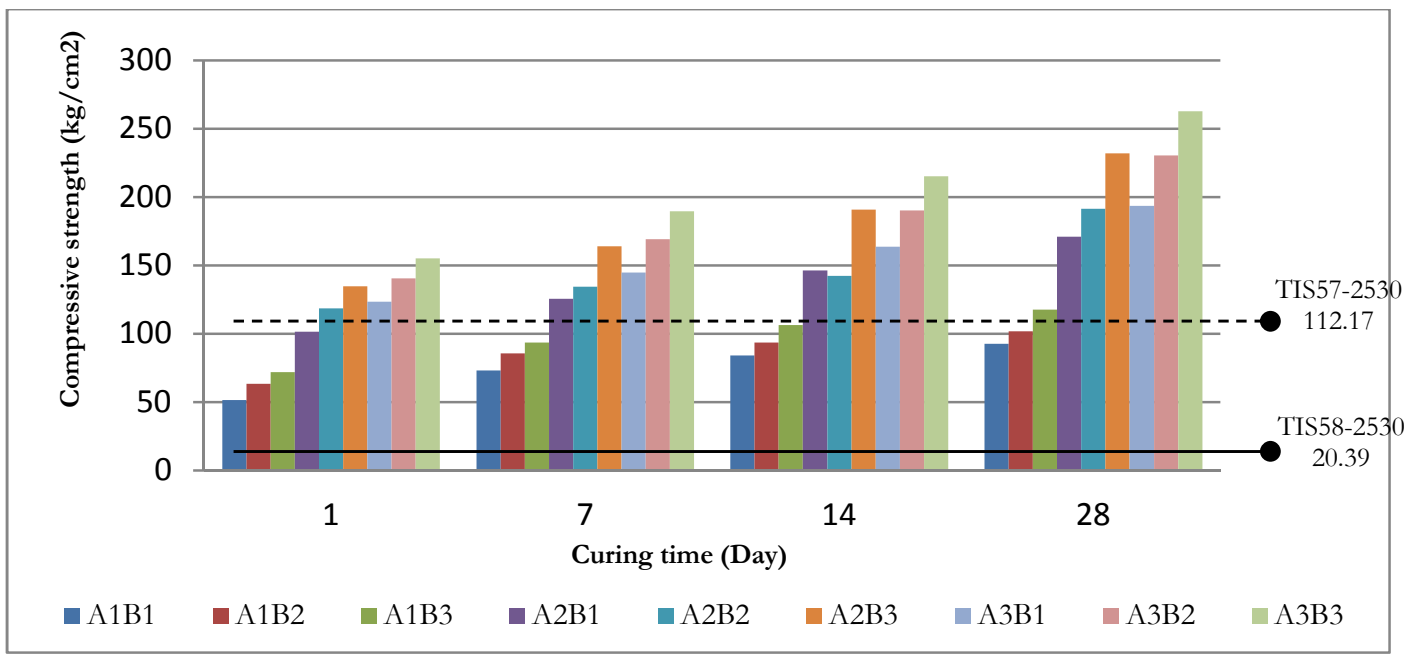

Fig 3. Compressive strength of geopolymer sample.

\subsection{Heavy Metal Concentration}

The data in Table 1 show that both of raw materials (alumina and silica waste) are hazardous waste by comparing the heavy metal concentration in the digestive solution with the standard concentration level set by the Ministry of Industry. To provide the usage of waste materials, the heavy metals have to be fixed within the structure of an aluminosilicate gel. So after the production of geopolymer, the total concentrations of heavy metal were estimated again to claim that the geopolymer products are no longer hazardous waste.

According to the data in Table 4, the results reveal that the concentration of heavy metal of the sample were within both of the standard concentration level set by The Ministry of Industry, Total Threshold Limit Concentration (TTLC) and Soluble Threshold Limit Concentration (STLC) which claim that the geopolymer products are no longer hazardous waste. After the solidification, the heavy metal concentration are lower than their raw materials because the heavy metal were fixed within the structure of aluminosilicate 
gel [10] and some were reacted in an adsorption on specific binder sites of mineral surface and physical retention in a porous structure [7].

Table 4. Heavy metal concentration estimated by Inductively Coupled Plasma Optical Emission Spectrometer (ICP-OES) and standard concentration level set by The Ministry of Industry, Total Threshold Limit Concentration (TTLC) and Soluble Threshold Limit Concentration (STLC).

\begin{tabular}{ccccc}
\hline Heavy metal & $\begin{array}{c}\text { Concentration } \\
(\mathbf{m g} / \mathbf{k g})\end{array}$ & $\begin{array}{c}\text { TTLC } \\
(\mathbf{m g} / \mathbf{k g})\end{array}$ & $\begin{array}{c}\text { Concentration } \\
(\mathbf{m g} / \mathbf{l})\end{array}$ & $\begin{array}{c}\text { STLC } \\
(\mathbf{m g} / \mathbf{l})\end{array}$ \\
\hline $\mathrm{Cr}$ & 29.8 & 2,500 & 0.61 & 5 \\
$\mathrm{Cu}$ & 15.9 & 2,500 & 0.50 & 25 \\
$\mathrm{~Pb}$ & 108 & 1,000 & 2.13 & 5 \\
$\mathrm{Zn}$ & 297 & 5,000 & 7.70 & 250 \\
\hline
\end{tabular}

\subsection{Microstructure}

Scanning Electron Microscopy (SEM) was used to analyze the microstructure of the highest compressive strength (A3B3) compare with the lowest compressive strength sample (A1B1) the results are showed in Fig 4.

The element composition of aluminosilicate gel consisted primarily of silicon, aluminium and sodium with smaller concentrate of calcium, maginesium, potassium and iron [11]. All the evidence appeared to indicate that the rising of $\mathrm{Si} / \mathrm{Al}$ and decreasing of $\mathrm{NaOH} / \mathrm{Na}_{2} \mathrm{SiO}_{3}$ ratio can improve the compressive strength at every curing time. This method aims to study the microstructure of sample after solidified. In Fig. 4 show that in sample A3B3, the structure were homogeneously mixed without rough texture or cracks. In the other hand, there are a lot of non-react particle within sample A1B1 and distinctly see cracks and rough texture.

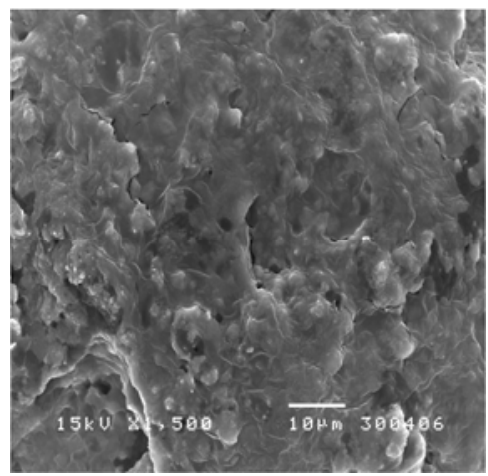

(a)

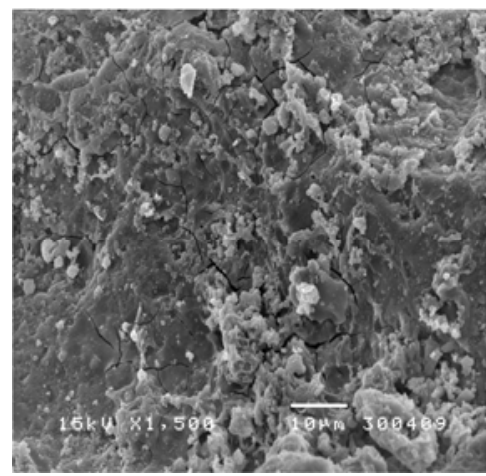

(b)

Fig 4. Microstructure pictures of (a) the best proportion sample [A3B3] compare with (b) sample [A1B1].

\section{Conclusions}

Alumina and silica waste has proven to be an effective raw material in geopolymer production because it's chemical characteristic. The main reaction product of the alkaline activation to alumina and silica waste is an amorphous polymer, an aluminosilicate whose chemical composition and microstructure vary depending on the nature of the activator used. In this research, alumina and silica waste were chosen to be raw material, sodium hydroxide and sodium silicate as an alkaline activated solution. The results revealed that at the ratio of $\mathrm{Si} / \mathrm{Al}=3$ and $\mathrm{NaOH} / \mathrm{Na}_{2} \mathrm{SiO}_{3}=0.5$ were given the highest compressive strength $(262.8$ $\left.\mathrm{kg} / \mathrm{cm}^{2}\right)$ tested at 28 curing days and the compressive strength can develop by the curing time. The geopolymer productions are also the utilization of hazardous waste. The study of heavy metal concentration indicated that after the formation of geopolymer, the heavy metal were fixed within the structure indicated by the smaller amount of concentration and it has proven that geopolymer products are no longer the hazardous waste. 


\section{Acknowledgement}

The authors would like to express great thanks for the help of the Environmental Engineering Department and the Civil Engineering Department, Faculty of Engineering, Chulalongkorn University for the use of laboratory and instruments.

\section{References}

[1] A. Ferdinandez-Jimenez, and A. Palomo, "Characterisation of fly ashes. Potential reactivity as alkaline cements," Fuel, vol. 82, pp. 2259-2265, 2003.

[2] P. Duxson, J. L. Provis, G. C. Lukey, S. W. Mallicoat, W. M. Kriven, and J. S. J. van Deventer, "Understanding the relationship between geopolymer composition, microstructure and mechanical properties," Colloids Surf. A physicochem. Eng. Asp., vol. 269, pp. 47-58, 2005.

[3] C. Shi, and A. Fernandez-Jimenez, "Stabilization/solidification of hazardous and radioactive wastes with alkali-activated cement," Journal of Hazardous Materials, vol. 137, pp. 1656-1663, 2006.

[4] ASTM C109/C109M-07, "Standard test method for compressive strength of hydraulic cement mortars (using $5 \mathrm{~cm}$ cube specimen)," Annual book of ASTM standard, 2008.

[5] D. N. Huntizinger, and T. D. Eatmon, "A life-cycle assessment of Portland cement manufacturing: comparing the traditional process with alternative technologies," Journal of Cleaner Production, vol. 17, pp. 668-675, 2009.

[6] Available at http://www.epa.gov/osw/hazard/testmethods/sw846/pdfs/3050b.pdf

[7] G. Zhen, X. Lu, X. Cheng, H. Chen, X. Yan, and Y. Zhao, "Hydration process of the aluminate 12CaO.7Al2O3-assisted Portland cement-based solidification/stabilization of sewage sludge," Construction and Building Materials, vol. 30, pp. 675-681, 2012.

[8] S. Demie, M. F. Nuruddin, N. Shafiq, "Effects of micro-structure characteristics of interfacial transition zone on the compressive strength of self-compacting geopolymer concrete," Construction and Building Materials, vol. 41, pp. 91-98, 2013.

[9] L. K. Turner, and F. G. Collins, "Carbon dioxide equivalent (CO2-e) emissions: a comparison between geopolymer and OPC cement concrete," Construction and Building Materials, vol. 43, pp. 125-130, 2013.

[10] I. Perna, and T. Hanzlicek, "The solidification of aluminium production waste in geopolymer matrix," Journal of Cleaner Production, vol. 84, pp. 657-662, 2014.

[11] M. Torres- Carrasco, and F. Puertas, "Waste glass in the geopolymer preparation, Mechanical and microstructural characterisation," Journal of Cleaner Production, vol. 90, pp. 397-408, 2015.

[12] Available at http://www.fio.co.th/p/tisi_fio/fulltext/TIS57-2533.pdf

[13] Available at http://www.fio.co.th/p/tisi_fio/fulltext/TIS58-2533.pdf 